\title{
'MASUK NAPI KELUAR SANTRI': PEMBINAAN NARAPIDANA BERBASIS PESANTREN DI LAPAS KELAS II A KOTA LUBUKLINGGAU
}

\author{
Savitri Restu Wardhini \\ STAI-Bumi Silampari Lubuklinggau, Indonesia \\ srwdhini26@gmail.com \\ Rama Wijaya K.W \\ STAI-Bumi Silampari Lubuklinggau, Indonesia \\ aldiscooter7@gmail.com \\ Pasiska \\ STAI-Bumi Silampari Lubuklinggau, Indonesia \\ bruspasiska@gmail.com
}

\begin{abstract}
This research examine the psychology of communication in the community fostered at the Class II A Lubuklinggau penitentiary facility. The research method used is qualitative research with a case study approach, then in data collection by interviewing, documentation and in data processing used with data reduction, then the presentation of the data and in the end the data is concluded. The communication psychology of clerics and prisoners in the class II A penitentiary boarding school in Lubuklinggau City is very influential. Because some prisoners have shown a positive response while receiving guidance at this pesantren. Based on the results of observations, interviews, and documentation, the researchers got the results that the implementation of strategic management in the Class II A penitentiary of Lubuklinggau City ran optimally, it can be proven that the number of prisoners after leaving the coaching process can live and survive and are able to be accepted in the community, although not yet within the scope broad.
\end{abstract}

Keyword; prisoners, psychology of communication, Lubuklinggau penitentiary.

\begin{abstract}
Abstrak: Penelitian ini mengkaji psikologi komunikasi dalam masyarakat binaan di Lapas Kelas II A Lubuklinggau. Metode penelitian yang digunakan adalah penelitian kualitatif dengan pendekatan studi kasus, kemudian dalam pengumpulan data dengan wawancara, dokumentasi dan dalam pengolahan data digunakan dengan reduksi data, kemudian penyajian data dan pada akhirnya data disimpulkan. Psikologi komunikasi kiai dan narapidana di LP kelas II A di Kota Lubuklinggau sangat berpengaruh. Pasalnya, beberapa napi sudah menunjukkan respon positif saat menerima pembinaan di pesantren ini. Berdasarkan hasil observasi, wawancara, dan dokumentasi, peneliti mendapatkan hasil bahwa penerapan manajemen stratejik di Lapas Kelas II A Kota Lubuklinggau berjalan optimal, dapat dibuktikan bahwa jumlah narapidana setelah keluar dari proses pembinaan dapat hidup dan bertahan serta mampu diterima di masyarakat walaupun belum dalam cakupan yang luas.
\end{abstract}

Kata kunci; narapidana, psikologi komunikasi, penjara Lubuklinggau.

(C) Author et al, Licensee Psychosophia, Islamic Psychology Program, IAIN Syaikh Abdurrahman Siddik Bangka Belitung, Indonesia. Psychosophia strongly support the Open Access Initiative. Abstract and full text of the article published by Psychosophia are freely accessible to everyone immediately after publication. This is an Open Access article distributed under the terms of the Creative Commons Attribution License, which permits unrestricted use, distribution, and reproduction in any medium, provided the original work is properly cited.

| Psychosophia Vol. 2, No. 2 (2020) Page 111 of 15

Submission Date Accepted Date

Review Date Publish Date
November 05, 2020 November 06, 2020 ; November 26, 2020 December 20, 2020 


\section{PENDAHULUAN}

Pidana penjara merupakan salah satu bagian dari sanksi pidana pokok yang sudah diterapkan di indonesia. Selain pidana penjara terdapat pula pidana denda, pidana kurungan dan pidana mati, pidana penjara terdapat di lembaga pemasyarakatan (Wibawa, 2018).

Lembaga pemasyarakatan merupakan salah satu bagian dalam sistem peradilan pidana yang bertugas melaksanakan pembinaan terhadap narapidana yang sedang menjalani masa hukuman (Putra, Yuliartini, \& Mangku, 2020). Sistem peradilan digunakan sebagai bentuk upaya menanggulangi kejahatan. Pada sistem peradilan pidana terdapat empat komponen (sub sistem), sub sistem kepolisian, sub sistem kejaksaan, sub sistem pengadilan pemasyarakatan (Abdullah, 2015).

Selanjutnya pelaksanaan pengadilan pemasyarakatan yang merupakan bagian dari sub sistem peradilan pidana tersebut perlu segera dilakukan pembaharuan (Hutabarat, 2017). Hal ini mengingat sebagian besar sanksi pidana yang sekarang ada baik itu dalam Kitab Undang-Undang Hukum Pidana (KUHP) maupun dalam konsep Kitab UndangUndang Hukum Acara Pidana Baru masih menggunakan bentuk sanksi berupa pidana penjara. Tujuan dijatuhkannya pidana penjara adalah untuk melindungi masyarakat maupun untuk memperbaiki hidup pelaku. Perkembangan selanjutnya pidana penjara dijatuhkan agar si pelakunya merasakan hukuman sebagai pembalasan (Bahagiati, 2020). Pelaksanaan pidana penjara dengan sistem pemasyarakatan tidak hanya ditujukan untuk mengayomi masyarakat dari bahaya kejahatan melainkan juga untuk mengayomi dan memberi bekal hidup orang-orang yang tersesat karena melakukan tindak pidana (Rahmah, 2017). Namun kenyataannya tidak mudah mewujudkan tujuan mulia tersebut sebab praktek di lapangan masih banyak ditemui kendala dan hambatan diantaranya masih ditemukan berbagai bentuk pelanggaran di Lembaga Pemasyarakatan (Dwiatmodjo, 2013).

Akhir-akhir ini terdengar bahwa narapidana yang sedang menjalani pembinaan di suatu lembaga pemasyaratan ternyata masih bisa melaksanakan kejahatannya dari dalam tembok penjara (Tohari \& Rokhim, 2020). Badan Narkotika Nasional (BNN) bekerja saama dengan Kementrian Hukum dan HAM mendapati tujuh narapidana yang selama ini melakukan peredaran narkoba dari dalam lembaga pemasyarakatan Nusakambangan Cilacap, Jawa Tengah. Ketujuh napi itu tiba di gedung BNN, Jakarta, Rabu dini hari 28 november 2012 sekitar pukul 02.00 WIB. Kepala Bagian Hubugan Masyarakat BNN Komisaris Besar Pol. Sumirat Dwiyanto mengatakan mereka semua merupakan pengendali narkoba yang diedarkan di luar penjara (Dwiatmodjo, 2013).

Berikutnya di tahun 2018, ratusan narapidana di lembaga pemasyarakatan kelas II A Banda Aceh melarikan diri pada kamis malam 29 November 2018 saat waktu shalat maghrib berjamaah. Kepala bagian humas direktorat jenderal pemasyarakatan ade kusmanto menjelaskan, kejadian ini berawal saat beberapa penghuni Lapas meminta melaksanakan shalat magrib berjamaah. Waktu beribadah tersebut digunakan 
beberapa orang narapidana untuk memprovokasi narapidana lainnya untuk melarikan diri (Wismabrata, 2018).

Kasus-kasus di atas menggambarkan paradoks bahwa meskipun berada di dalam penjara atau masa penghukuman beberapa yang menjadi narapidana tersebut belum merasa bersalah. Sehingga, membuatnya tetap mampu melakukan kejahatan atau pelanggaran hukum dengan pelaksanaan yang lebih terstruktur. Persoalan tersebut juga seperti membenarkan bahwa saat ini sering terdengar lembaga pemasyarakatan adalah sekolah tinggi ilmu kejahatan (Abdullah, 2015).

Lebih lanjut, persoalan tersebut memberikan kecemasan bahwa narapidana yang dipenjara dalam lembaga pemasyarakatan akan belajar melakukan kejahatan dengan level lebih tinggi dan dengan perencanaan yang lebih matang dengan narapidana lainnya. Sehingga nantinya setelah selesai menjalani hukuman atau menjadi seorang narapidana dan keluar dari lembaga pemasyarakatan akan mengulangi melakukan kejahatan atau pelanggaran hukum lainnya (residivis) (Sandi, 2016).

Hal tersebut bertolak belakang dengan maksud dan tujuan Lembaga Pemasyarakatan itu sendiri, yang mana Lembaga Pemasyarakatan sebagai sub sistem paling terakhir yang langsung berhadapan dengan narapidana untuk melaksanakan pembinaan, mempunyai posisi yang stategis dalam mewujudkan tujuan akhir dari Sistem Peradilan Pidana (Prawira \& Suteki, 2017).

Lebih lanjut Lembaga Pemasyarakatan juga dijadikan tempat muhasabah diri bagi mereka yang menciderai peran sosial mereka dengan perilaku yang tidak baik dan cukup beralasan untuk dikenai hukuman dan membuat mereka menjadi terpidana yang dijatuhi hukuman oleh kejaksaan dan kehilangan kemerdekaannya biasa disebut dengan narapidana (uu-no-12-tahun-1995-tentangpemasyarakatan, n.d.). Di lembaga pemasyarakatan, para narapidana akan dibina dan diharapkan setelah habis masa hukumannya, keluar dari lembaga pemasyarakatan menjadi orang baik.

Pelaksanaan pembinaan pada narapidana tersebut merupakan upaya dalam pengembalian narapidana menjadi masyarakat yang baik. Tidak hanya bersifat material atau sprititual saja, melainkan keduanya harus berjalan dengan seimbang, ini merupakan salah satu hal pokok yang menunjang narapidana mudah dalam menjalani kehidupannya setelah selesai menjalani masa pidana.

Oleh karena itu, persoalan narapidana dan Lembaga Pemasyarakatan bukanlah sebuah istilah yang asing bagi setiap orang. Narapidana juga merupakan istilah yang biasa digunakan untuk disematkan pada mereka yang sedang menjalani masa hukuman yang dijatuhkan oleh pengadilan, terkait dengan keterlibatannya dalam suatu tindakan buruk yang melanggar peraturan atau perundang-undangan yang berlaku.

Salah satu dampaknya angka kriminalitas meningkat dengan keberagaman aksi kekerasan di dalamnya baik dari perbuatan individu maupun perbuatan kelompok yang mengakibatkan kerugian untuk orang lain (Indonesia, n.d.). karena adanya perubahan tata nilai dan tata kehidupan 
yang serba keras, bahkan tradisi nenekmoyang yang dikenal beradab telah terkikis oleh budaya baru yang serba modern ini, dan tidak sedikit dari mereka terseret ke dalam penjara atau Lembaga Pemasyarakatan karena perbuatan menyimpang yang mereka lakukan melanggar hukum. Untuk menyikapi hal tersebut manusia dituntut untuk berusaha memegang teguh nilai-nilai moral.

Terkait persoalan tersebut proses pembimbingan narapidana di Lembaga Pemasyarakatan diharapkan mampu membentuk kepribadian serta mental narapidana yang dianggap tidak baik dimata masyarakat menjadi berubah kearah yang normal dan sesuai dengan norma dan hukum yang berlaku. Di dalam pelaksanaan pembinaan ini memerlukan kerjasama dari komponenkomponen yang menunjang keberhasilan proses pembinaan narapidana, yaitu petugas Lembaga Pemasyarakatan, narapidana, dan masyarakat. (Harsono, 1995) Hal ini dikarenakan ketiganya saling berhubungan satu dengan yang lainnya sebagai suatu sistem.

Sistem pemasyarakatn yang merupakan sistem pembinaan narapidana diatur dalam Pasal 6 Undang-Undang Nomor 12 Tahun 1995 yang berdasarkan asas: Pengayoman, Persamaan perlakuan dan pelayanan, Pendidikan, Pembimbingan, Penghormatan herkat dan martabat manusia. Kehilangan kemerdekaan merupakan satu-satunya penderitaan dan Terjaminnya hak untuk tetap berhubungan dengan keluarga dan orang-orang tertentu (uu-no-12-tahun1995-tentang-pemasyarakatan, n.d.).

Proses pelaksanaan pembinaan narapidana yang telah di jabarkan tersebut, proses pembinaan yang dimaksudkan juga terdapat di Lembaga Pemasyarakatan kelas II A Kota Lubuklinggau. Lembaga Pemasyarakatan kelas II A Kota Lubuklinggau sendiri melakukan pembinaan dengan cara membuat Pesantren di dalam Lembaga Pemasyarakatan dengan kegiatan rutin yang dimulai sejak pagi hingga sore.(Dendy Aprihadi, 2019)

Kegiatan tersebut antara lain mengaji, siraman rohani, shalat berjamaah dan kegiatan-kegiatan islami lainnya. Tidak menutup kemungkinan di Lembaga Pemasyarakatan kelas II A Kota Lubuklinggau juga terjadi pelanggaranpelanggaran yang dilakukan oleh beberapa narapidana.

Kemudian pada bulan juni 2019 di blok bougenvil sejumlah narapidana tipikor kedapatan membawa handphone lengkap beserta charger dan perlengkapan lainnya. Hal ini membuktikan bahwa dalam lapas yang memiliki pesantren tersebut masih terdapat beberapa narapidana yang mangkir dari aturan (Banyak Napi Bawa Handphone Dalam Sel, Kanwil Kemenkumham Sumsel Bakal Pasang X-Ray di Tiap Lapas, n.d.).

Keadaan demikian tentu menjadi keprihatinan bersama apakah ada yang salah dalam proses pelaksanaan pidana dan pembinaan narapidana di lembaga persmayarakatan selama ini. Penegakkan hukum tidak hanya dilihat dalam kacamata undang-undang saja. Tetapi juga harus dilihat secara utuh dengan melibatakan semua unsur yang ada, seperti moral, perilaku dan budaya.

Fenomena-fenomena yang terjadi peneliti memilih Lembaga Pemasyarakatan kelas II A kota 
lubuklinggau yang menggunakan metode pesantren dengan visi "masuk napi keluar santri" yang menjadi obyek penelitian. Masuk napi keluar santri menjadi topik yang menarik untuk dijadikan obyek kajian dengan judul Masuk Napi Keluar Santri" Di Lembaga Pemasyarakatan Kelas II A Kota Lubuklinggau" Analisis Psikologi Komunikasi.

\section{METODE PENELITIAN}

Pada bagian ini peneliti menguraikan secara singkat dan jelas metode yang digunakan dalam proses penelitian. Seperti yang dapat dilihat metode yang digunakan dalam penelitian ini merupakan metode kualitatif yang berfokus pada menekankan analisis proses dari proses berfikir induktif yang berkaitan dengan dinamika hubungan antar fenomena yang akan diamati, dan senantiasa menggunakan logika ilmiah. Penelitian kualitatif merupakan suatu model penelitian humanistic, yang menempatkan manusia sebagai subyek utama dalam peristiwa sosial dan budaya.

Denzin dan Licoln mengatakan di dalam buku metodelogi penelitian bahwa penelitian kualitatif merupakan penelitian yang menggunakan latar alamiah dengan maksud menafsirkan fenomena yang terjadi dan dilakukan dengan cara melibatkan metode yang ada (Setiawan, 2018).

Sedangkan menurut Sugiyono metode penelitian kualitatif merupakan penelitian yang berlandaskan pada filsafat post positivisme, digunakan untuk meneliti pada kondisi obyek yang alamiah, (sebagai lawannya eksperimen) dimana peneliti adalah sebagai instrumen kunci, pengambilan sampel sumber data dilakukan secara purposive dan snowball, teknik pengumpulan dengan tri-anggulasi (gabungan), analisis data bersifat induktif atau kualitatif, dan hasil penelitian kualitatif lebih menekankan makna dari pada generalisasi (Sugiyono, 2013).

Lebih lanjut metode penelitian kualitatif bersifat subjektif dari sudut pandang partisipan secara deskriptif sehingga hasilnya tidak dapat digeneralisasikan. Dengan kata lain, metode riset ini lebih bersifat memberikan gambaran secara jelas suatu permasalahan sesuai dengan fakta di lapangan dan metode penelitian ini sangat cocok digunakan untuk menganalisis atau mengetahui tolak ukur suatu permasalahan terlebih dalam mengetahui kemajuan atau perkembangan suatu permasalahan.

Pada penelitian ini studi kasus yang dilakukan di Lembaga Pemasyarakatan mencari tahu kondisi psikologi komunikasi dan manajemen strategi dalam pembinaan narapidana di Lembaga Pemasyarakatan kelas II A Kota Lubuklinggau. Jenis penelitian yang akan digunakan oleh penulis yaitu metode atau data kualitatif.

Pada penelitian yang berjudul "masuk napi keluar santri" di lembaga pemasyarakatan kelas II A Kota Lubuklinggau analisis psikologi komunikasi. Peneliti melakukan penelitian di kantor wilayah lembaga pemasyarakatan kelas II A Kota lubuklinggau yang beralamat di Jl.Depati Said, No.11, Kec. Lubukinggau Barat 1, kota Lubuklinggau, Prov Sumatera Selatan.

Adapun sumber data yang penulis gunakan dalam penelitian ini ada dua 
macam yaitu data primer dan data sekunder.

1. Data primer

Sumber data primer merupakan "data yang dikumpulkan langsung dari individu-individu yang diselidiki" (Sugiyono, 2013). Dalam penelitian ini data primer merupakan data utama yang di peroleh dari beberapa narapidana yang menjadi santri di pesantren narapidana lapas kelas II A Kota Lubuklinggau.

2. Data sekunder

Sumber data sekunder merupakan "data yang menjadi pendukung untuk melengkapi data primer"(Sugiyono, 2013). Dalam hal ini, data sekunder merupakan data pendukung yang di peroleh dari ustaz atau pembina pesantren narapidana di lapas kelas II A Kota Lubuklinggau.

Pada sebuah proses penelitian metode pengumpulan data yang benar, akan menghasilkan data yang memiliki kredibilitas tinggi. Selanjunya berikut tahap-tahap pengumpulan data tidak boleh salah dan harus dilakukan dengan cermat dan sesuai prosedur dan ciri-ciri penelitian kualitatif.

Terkait persoalan metode penlitian kualitatif, ada beberapa metode data dalam pengumpulan data kualitatif, sebagai berikut :

1. Metode Observasi

Observasi merupakan proses pengamatan dan pencatatan dengan sistematis atas fenomenafenomena yang diteliti, baik di lakukan secara langsung maupun tidak langsung (Sujarweni, 2014). Observasi dilakukan dengan mengamati langsung di lapangan tentang psikologi komunikasi narapidana, dan proses pelaksanaan manjemen strategi dalam proses pembinaan narapidana di pesantren Narapidana Lembaga Pemasyarakatan kelas II A Kota Lubuklinggau.

2. Wawancara

Wawancara merupakan alat pengumpulan informasi dengan cara mengajukan sejumlah pertanyaan secara lisan untuk menjawab secara lisan (Sujarweni, 2014). Pada hakikatnya wawancara merupakan kegiatan untuk memperoleh informasi secara mendalam tentang sebuah isu atau tema yang diangkat dalam sebuah penelitian. Wawancara kualitatif dilakukan bila penulis bermaksud untuk menggali informasi yang terjadi dilapangan secara langsung yang berkaitan dengan individu dan topic yang diteliti, dan bermaksud melakukan eksplorasi terhadap isu trsebut, suatu hal yang tidak dapat dilakukan dengan pendekatan lain.

3. Dokumentasi

Dokumentasi merupakan "pencarian data mengenai hal-hal atau variabel yang berupa catatan, transkrip, buku, surat kabar dan sebagainya(Arikunto, 1992)." Teknik dokumentasi ini digunakan untuk melengkapi observasi dan wawancara, juga untuk mengambil data tentang jumlah narapidana, karyawan, sarana dan prasarana yang dimiliki oleh Lembaga 
Pemasyarakatan kelas II A Kota Lubuklinggau.

Dokumentasi ini berguna untuk mengecek data yang telah terkumpul. Maksudnya, jika nanti ada yang terbuang/kurang peneliti masih bis memanfaatkan data lain. Atau bisa dikatakan dokumentasi merupakan bukti bahwa peneliti benar- benar melakukan sebuah penelitian.

Analisa data ini digunakan untuk mengumpulkan data-data yang terkait. Setelah data primer dan data sekunder terkumpul, kemudian diklarifikasikan sesuai dengan pertanyaan penelitian yang telah ditentukan. Analisis yang berarti menguraikan atau memisah-misahkan.

Terkait persoalan analisa data, peneliti menggunakan cara analisa data Miles and Huberman, yang mengemukakan di dalam buku Sugiyono metode penelitian kualitatif bahwa "aktivitas dalam analisis data kualitatif dilakukan secara interaktif dan berlangsung secara terus menerus sampai tuntas, sehingga datanya sudah jenuh"(Sugiyono, 2008). Dengan langkah-langkah analisis sebagai berikut:

1. Data reduction (Reduksi Data), memilih hal-hal pokok, memfokuskan pada hal-hal yang penting. Dalam penelitian ini penulis menganalisis hasil wawancara dan memilih hal-hal yang berkaitan dengan rumusan masalah yang telah ditentukan. Dengan demikian, data yang telah direduksi akan memberikan gambaran yang jelas, dan mempermudah peneliti untuk melakukan pengumpulan data selanjutnya.

2. Data Display (penyajian data)

Setelah data direduksi, maka langkah selanjutnya adalah mendisplaykan data. Dalam penelitian kualitatif, penyajian data dapat dilakukan dalam bentuk uraian singkat, bagan hubungan antar kategori, dan selanjutnya. Dalam penelitian ini peneliti menggunakan penyajian data merangkum hasil wawancara bersama informan telah di pilih. Dengan mendisplaykan data, maka akan memudahkan untuk memahami apa yang terjadi, merencanakan kerja selanjutnya berdasarkan apa yang telah dipahami tersebut.

3. Conclusion Drawing/verification Langkah ke tiga dalam analisis data kualitatif menurut Miles and Huberman adalah penarikan kesimpulan dan verifikasi. "kesimpulan awal yang dikemukakan masih bersifat sementara, dan akan berubah bila ditemukan bukti-bukti yang kuat yang mendukung pada tahap pengumpulan berikutnya" (Sugiyono, 2013). Tetapi bila kesimpulan yang dikemukakan pada tahap awal, didukung oleh bukti-bukti yang valid dan konsisten saat peneliti kembali ke lapangan mengumpulkan data, maka kesimpulan yang dikemukakan kredibel.

Dengan demikian kesimpulan dalam penelitian kualitatif mungkin dapat menjawab rumusan masalah 
yang dirumuskan sejak awal, tetapi mungkin juga tidak, karena masalah dalam penelitian kualitatif masih bersifat sementara dan akan berkembang setelah peneliti berada di lapangan.

Untuk itu dalam menguji tingkat kredibilitas dan keabsahan data, peneliti menggunakan teknik triangulasi, yaitu dengan cara mengecek data dari berbagai sumber dengan berbagai cara dan berbagai waktu (Sujarweni, 2014). Berikut teknik tringulasi yang digunakan :

1. Triangulasi Sumber

2. Triangulasi Teknik

3. Triangulasi Waktu.

\section{HASIL DAN PEMBAHASAN}

Adapun Kedudukan Lembaga Pemasyarakatan sangat berperan penting dalam mewujudkan "Due Process Of Law" (Proses hukum yang berkeadilan), sebagaimana yang tercantum dalam Undang Undang Dasar Republik Indonesia Tahun 1945 dan Undang Undang Nomor 12 Tahun 1995 Tentang Pemasyarakatan.

Pemasyarakatan merupakan salah satu perangkat peradilan pidana, oleh karena itu sasaran, arah dan arah strategis program Lembaga Pemasyarakatan sangat penting dalam penegakan hukum (Low Enforcement) di Indonesia, karena konsep pemasyarakatan merupakan bagian pembangunan dibidang hukum, sebagaimana yang diarahkan dalam RPJM dan RPJP Nasional (Sadli Putra, 2019).

Disamping itu, dalam implementasi faktual, terlihat jelas bahwa usaha pemerintah dalam membina orang orang yang telah melakukan tindak pidana dan oleh hakim dijatuhi hukuman pidana penjara, di mulai dengan Masa Pengamatan, Pengenalan, dan Penelitian Lingkungan (MAPENALING) bagi warga binaan yang baru masuk pertama kali di Lembaga Permasyarakatan tersebut, dengan tujuan agar dapat memahami tata tertib, hak dan kewajiban serta larangan dalam proses permasyarakatan yang bertujuan mengembalikannya menjadi anggota masyarakat yang baik, setelah dibina secara intensif, terukur dan terprogram di Lembaga Pemasyarakatan.

Sebagai salah satu Lembaga Pemasyarakatan di Indonesia, tentunya Lapas Klas IIA Lubuklinggau turut memberikan kontribusi positif bagi pembangunan hukum serta melakukan pebinaan berkala dan berkelanjutan bagi Warga Binaan Pemasyarakatan (WBP) melalui kegiatan keagamaan, olahraga, seni budaya, pendidikan dan kegiatan khusus lainnya. Di Provinsi Sumatera Selatan, Khususnya di Wilayah Kotamadya Lubuklinggau, Kabupaten Musi Rawas Dan Kabupaten Musi Rawas Utara, dimana Lapas Klas IIA Lubuklinggau menampung Warga Binaan, Anak Didik serta Tahanan dari satu kota madya dan dua Kabupaten tersebut (Sadli Putra, 2019).

Sehingga dengan pembinaan yang dilakukan dapat terwujud dan tercapai tujuan "Konsep Sistem Pemasyarakatan" yakni untuk mengembalikan Warga Binaan Pemasyarakatan (WBP) menjadi warga yang baik, serta melindungi WBP terhadap kemungkinan diulanginya tindak pidana, dan dalam penerapan pembinaan tetap mengacu kepada nilai nilai Pancasila, disamping aspek tata kelola pembinaan yang memiliki ciri ciri 
preventif, kuratif, rehabilitatif dan edukatif.

Lapas Kelas II A lubuklinggau Lembaga Permasyarakatan Kelas IIA Lubuklinggau terletak dijalan Depati Said. Kelurahan Ulak Lebar Kecamatan Lubuklinggau Barat II Propinsi Sumatera Selatan. Mulai dibangun Tahun 1982, diatas tanah seluas $16.545 \mathrm{~m}^{2}$ dan luas bangunan kantor $6.649 \mathrm{~m}^{2}$ luas sarana $9.896 \mathrm{~m}^{2}$ (Novita, 2019). Dengan daya tampung penghuni sebanyak 549 orang yang terdiri dari:

a. Blok Kartini dengan luas bangunan $99.25 \mathrm{M}^{2}$

b. Blok Diponegoro (Dua Lantai) dengan luas bangunan $590 \mathrm{M}^{2}$

c. Blok Sudirman (Dua Lantai) dengan luas bangunan $590 \mathrm{M}^{2}$

d. Blok Hasanudin (Dua Lantai) dengan luas bangunan $285 \mathrm{M}^{2}$

e. Blok Sultan Mahmud Badaraudin dengan luas bangunan $40 \mathrm{M}^{2}$

f. Blok Gatot Subroto dengan luas bangunan $62 \mathrm{M}$

g. Bimker dengan luas bangunan $137.8 \mathrm{M}^{2}$

h. Masjid dengan luas bangunan $86 \mathrm{M}^{2}$, Kondisi bangunan baik.

i. Ruang Aula serbaguna dengan luas 240 $\mathrm{M}^{2}$

j. Ruang Kantor, terdiri dari 2 lantai.

k. Fasilitas Rumah Dinas sebanyak 13 unit.

\section{Analisis Psikologi Komunikasi di Pesantren Narapidana}

Komunikasi merupakan upaya penyampaian pesan dari komikator kepada komunikan dengan tujuan untuk memberikan motivasi, mempengaruhi atau hanya sekedar memberikan informasi (Susriyanti \& Nardo, 2019).
Dalam proses komunikasi tatanan komunikasi harus diperhatikan agar mencapai arah yang tepat. Terdapat beberapa tatanan komunikasi dalam ilmu komunikasi diantaranya: komunikasi intrapersonal, komunikasi interpersonal, komunikasi kelompok, komunikasi organisasi (Purba et al., 2020).

Selanjutnya, proses yang terjadi dalam analisis psikologi komunikasi pada penelitian ini adalah komunikasi interpersonal dan intrapersonal yaitu komunikasi yang berlangsung dengan diri sendiri dan orang lain.

Lebih lanjut penelitian ini menggunakan pendekatan psikologi behavioristik yaitu psikologi perilaku, yang fokus pada pola relasi antara stimulus, organisme, respon atau biasa disebut SOR (Faizah, 2015). Stimulus atau rangsangan merupakan suatu hal yang datang dari lingkungan yang dapat menyebabkan respon tertentu pada tingkah laku dalam hal ini yang disebut stimulus ialah proses pembinaan di dalam pesantren narapidana Lembaga Pemasyarakatan Kelas II A Kota Lubuklinggau seperti kebiasaan membaca buku mengaji, dan mendengarkan siraman rohani dalam komunikasi stimulus ini bisa disebut pesan.

Proses tersebut dikuatkan dengan hasil wawancara bersama bapak Dzulkipli selaku ustaz pembina di pesantren lembaga pemasyarakatan kelas II A Kota Lubuklinggau, dengan informasi sebagai berikut:

"Para narapidana disini memiliki kegiatan rutin setiap harinya yaitu pada pagi hari mendengarkan ceramah agama yang di isi langsung oleh saya atau kadang mengundang ustaz dari luar. Disela-sela ceramah agama 
para narapidana juga melakukan sharing untuk menambah kepercayaan diri narapidana yang sudah hilang" (wawancara D, 2019).

Hasil wawancara tersebut membuktikan bahwa dalam proses pelaksanaan pembinaan narapidana di lembaga pemasyarakatan kelas II A Kota Lubuklinggau ada proses stimulus atau rangsangan yang berisi pesan guna untuk menjadi motivasi agar narapidana tidak merasa putus asa.

Selanjutnya setelah stimulus dalam aliran behaviorisme ada organisme. organisme merupakan orang yang menerima stimulus atau dalam komunikasi disebut komunikan dan dalam hal ini komunikan yaitu narapidana yang menjalani proses pembinaan di dalam lembaga pemasyrakatan kelas II A Kota Lubuklinggau. Apabila stimulus atau pesan dari proses pembinaan tersebut diterima menandakan adanya perhatian dari komunikan (organisme) yaitu narapidana. Yang bearti stimulus atau pesan tersebut efektif digunakan dalam proses pembinaan.

Proses tersebut dikuatkan pula dengan hasil wawancara bersama A seorang narapidana yang mendapatkan masa hukuman 7 tahun dan telah melewati selama 3,5 tahun sebagai berikut:

"kegiatan di pesantren ini sama seperti kegiatan di pengajian pada umumnya kami di ajarkan mengaji, shalat dan juga di ajarkan tetang agama. selama disini perubahan yang saya rasakan menjadi sedikit lebih bisa mengatur emosi, lebih rajin shalat dan juga sudah bisa mengaji, sangat berbeda dengan kegiatan saya dulu waktu sebelum menjadi narapidana di lembaga pemnasyarakatan ini' (wawancara D, 2019)."

Hasil wawancara tersebut membuktikan bahwa adanya perhatian terhadap stimulus yng diberikan oleh komunikator kepada organisme atau yang menjadi komunikan dalam hal ini yaitu narapidana.

Selanjutnya pesan atau stimulus yang di terima oleh narapidana atau organisme ini diolah oleh narapidana sehingga terjadi kesediaan untuk bertindak demi stimulus yang telah diterima atau dengan kata lain mengambil sikap. Ditambah dengan dukungan fasilitas serta dukungan dari lingkungan, maka akhirnya sikap yang diambil organisme atau komunikan menjadi sebuah tindakan yaitu perubahan perilaku dan perubahan tersebut merupakan respon. Respon tersebut merupakan narapidana yang telah menerima pembinaan dapat termotivasi dan semangat untuk menjadi manusia yang lebih baik lagi setelah pasca menerima pembinaan di lembaga pemasyarakatan kelas II A Kota Lubuklinggau.

Respon tersebut dikuatkan dengan hasil wawancara bersama bapak dzulkipli selaku ustaz Pembina di pesantren lapas yang melihat beberapa perubahan signifikan pada diri narapidana, dengan informasi sebagai berikut:

"Dalam proses pembinaan pasti ada hasil meskipun belum signifikan beberapa dari narapidana sudah terbiasa dengan kegiatan rohani tersebut bahkan sudah ada beberapa sudah bisa membantu temannya belajar mengaji ataupun belajar shalat. Karena pada dasarnya seorang narapidana memerlukan proses untuk menjadi manusia yang lebih baik. 
Terlebih dengan kondisi yang sudah tidak sama lagi (wawancara D, 2019)."

Karena pada dasarnya perubahan seseorang itu bergantung dengan bagaimana kondisi seseorang itu sendiri. Sebaik apapun pembinaan dilakukan jika tidak timbul kesadaran dalam diri narapidana tersebut tidak akan terjadi sebuah perubahan dan begitu juga sebaliknya sekecil apapun usaha dalam pembinaan apabila di dasari oleh individu yang ingin berubah maka perubhan tersebut tidak akan menjadi sebuah wacana.

Dari hasil dokumentasi pada tanggal 12 November 2019 ditemukannya bukti aktiivitas yang memperkuat bahwa proses pembinaan narapidana di pesantren Lembaga Pemasyarakatan kelas II A Kota Lubuklinggau berjalan dengan teratur dan maksimal. Dalam kegiatan tersebut beberapa narapida yang sudah bisa mengaji mengajarkan temannya yang lain, beberapa lagi ada yang membaca buku dan mendengarkan ceramah agama yang disampaikan oleh ustaz pembina. Dan disela sela waktu istirahat beberapa narapidana melakukan sharing kepada ustaz pembina.

Selanjutnya, berdasarkan hasil observasi, wawancara dan dikumentasi maka peneliti mendapatkan hasil bahwa psikologi komunikasi ustaz dan narapidana di pesantren narapidana lembaga pemasyarakatan kelas II A Kota lubuklinggau sangat berpengaruh. karena beberapa narapidana sudah menunjukkan respon positif selama mendapatkan binaan di pesantren ini meskipun belum dalam cangkupan yang luas.

Terkait persoalan tersebut pada dasarnya tidaklah mudah untuk dapat keluar dari zona keterpurukan yang dialami oleh para narapidana saat ini. Oleh karena itu semboyan masuk napi keluar santri harus selalu di gaungkan guna upaya untuk merubah paradigma masyrakat bahwa seorang narapidana pun bias menjadi lebih baik seperti layaknya manusia yang lainnya.

\section{Proses Pelaksanaan Manajemen Strategi LAPAS Berbasis Pesantren}

Seperti yang sudah dibahas sebelumnya bahwa dalam pelaksanaan pembinaan narapidana dengan metode pesantren dan semboyan masuk napi keluar santri pasti harus menggunakan menejemen strategi yang baik agar program tersebut dapat terealisasi dengan maksimal. menyusun suatu strategi merupakan suatu seni dan ada banyak pendekatan yang berbeda untuk melakukan tugas ini.

Merujuk pada teori menejemen strategi oleh Fred R. David menjelaskan bahwa proses manajemen strategi terdiri dari tuga tahapan, yaitu memformulasikan strategi, mengimplementasikan strategi, dan mengevaluasi strategi.

\section{Tahap Formulasi}

Stretegi antara lain menentapkan vivi misi, mengidentifikasi peluang dan tantangan yang akan di hadapi dari sudut pandang eksternal, menetapkan kelemahan dan keunggulan yang di miliki dari sudut pandang internal, menyusun rencana jangka panjang, membuat strategi-strategi alternatif dan memilih strategi tertentu yang akan dicapai.

Terkait hal ini, formulasi yang dilakukan oleh Lembaga Pemasyarakatan Kelas II A Kota Lubuklinggau yaitu 
dengan membuat konsep pembinaan narapidana dengan konsep pesantren dengan semboyan masuk napi keluar santri. yang dibina langsung oleh ustaz agar mampu mengarahkan narapidana menjadi manusia yang lebih baik lagi.

Proses formulasi tersebut dikuatkan dengan hasil wawancara bersama Bapak M selaku Kepala Sub Seksi Pembimbingan Kemayarakatan dan Perawatan sebagai berikut:

"pesantren narapidana ini dipilih karena dipandang mampu merubah pola pikir manusia dengan cara pembinaan akhlak. di pesantren narapidana ini narapidana di batu untuk lebih dekat dengan penciptaNya agar kelak ketika sudah selesai menjalani masa hukuman tidak akan melakukan kesalahan yang sama (wawancara M, 2019)."

Hasil wawancara tersebut membuktikan bahwa dalam pelaksanaan manajemen strategi di Lembaga Pemasyarakatan kelas II A Kota Lubuklinggau melalui tahap formulasi dengan semboyan masuk napi keluar santri yang bertujuan untuk merubah pola pikir narapidana agar bersemangat kembali dalam menjalani kehidupan. Karena pada hakikatnya teori se baik apapun tidak akan menjadi apa-apa tanpa implementasi. Maka tahap berikutnya adalah tahap implementasi.

\section{Tahap Implemantasi}

Tahap imlementasi merupakan suatu keputusan dari pihak yang berwenang dalam mengambil keputusan untuk menetapkan tujuan tahunan, membuat kebijakan, memotivasi pegawai, dan mengalokasikan sumber daya yang dimiliki sehingga strategi yang sudah diformulasikan dapat dilaksanakan.
Selanjutnya tahap formulasi dilakukan pengembangan strategi pendukung budaya, merencanakan struktur organisasi yang efektif. Mengatur ulang usaha yang dilakukan. Dalam hal ini, Lapas Kelas II A Kota Lubuklinggau melakukan implementasikan dengan cara membuat agenda rutin untuk para narapidana dimulai dari pagi hari para narapidana mendengarkan kultum atau ceramah lalu belajar mengaji dan shalat kamudian mengisi waktu senggang dengan membaca buku. Usaha ini dilakukan untuk menanamkan kebiasaankebiasaan baru bagi narapidana.Agar nanti kebiasaan tersebut ternaman walau masa penghukuman telah selesai atau di sebut degan bebas.

Proses implementasi tersebut dikuatkan dengan hasil wawancara bersama Bapak Dendi Prihadi selaku staf bagian pembinaan narapidana. Dengan informasi sebagai berikut:

"Terkait pembinaan di dalam blok santri kami melakukan berbagai upaya semaksimal mungkin dari mulai mendatangkan ustaz untuk langsung memberikan ceramah sekaligus dukungan moril kepada narapidana, lalu menciptakan suasana lokasi lapas yang sejuk dengan adanya taman agar membuat para narapidana tenang ketika menerima peembinaan dari ustaz binaan dan kami pun membangun kedekatan emosional dengan para narapidana guna membantu mereka mengembalikan kepercayaan diri mereka" (wawancara DA, 2019).

Hasil wawancara tersebut membuktikan bahwa Lapas Kelas II A Kota Lubuklinggau melakukan upaya dalam pengimplementasian strstegi dengan sangat maksimal karena untuk mewujudkan semboyan masuk napi 
keluar santri bukanlah hal mudah. Oleh karena itu memerlukan usaha dan upaya yang sangat maksimal. Selanjutnya setelah implementasi dilakukan untuk tetap megupayakan agar pelaksanaa implementasi selalu maksimal, maka perlu adanya tahap evaluasi.

\section{Tahap Evaluasi}

Sebelumnya telah dipaparkan bahwa manajemen strategi yaitu bertujuan untuk memunculkan strategi-strategi alternatif yang dapat dilaksanakan melalui pengabungan faktor eksternal dan internal (Rodiyah, Dirlanudin, \& Cadith, 2018).

Selanjutnya pada tahap evaluasi ini yang dilakukan oleh lembaga pemasyarakatan kelas II A Kota Lubuklinggau adalah dengan memberikan tingkatan kelas di pesantren narapidana kelas II A kota lubuklinggau guna memacu semangat narapidana agar terus belajar dan memang mengikuti proses pembelajaran bukan hanya karena berada di dalam pesantren lapas tersebut.

Lebih lanjut, proses pelaksanaan evaluasi tersebut dibuktikan dengan hasil wawancara bersama kepala lembaga pemasyarakatan kelas II A Kota Lubuklinggau dengan informasi sebagai berikut:

"blok santri ini kami buat dalam rangka memberikan semangat kepada narapidana karena dukungan moril sangat butuhkan para narapidana yang ada di lapas ini pun tidak semua masuk di blok santri karena untuk masuk ke dalam blok santri narapidana harus memulai perubahan dengan diri sendiri baru nanti apabila di pandang memang akan berubah akan dipindahkan ke blok santri. kami biasa menyebutnya naik kelas karena metote tersebut cukup membuat para narapidana termotivasi untuk menjadi lebih baik (wawancara IP, 2019).

Dari hasil dokumentasi pada tanggal 12 November 2019 ditemukannya bukti aktiivitas yang memperkuat bahwa proses pelaksanaan manajemen strategi di pesantren lembaga pemasyarakatan kelas II A Kota Lubuklinggau berjalan dengan teratur dan maksimal. Dalam kegiatan tersebut beberapa narapida sudah mulai menunjukkan perubahan yang sugnifikan melalui sikap walaupun belum dalam ruang lingkup yang luas.

\section{KESIMPULAN}

Berdasarkan hasil penelitian pada bab sebelumnya dari seluruh uraian dalam peneitian skripsi ini, maka penulis menyimpulkan bahwa pertanyaan yang ada pada rumusan masalah dapat terjawab yaitu :

1. Psikologi komunikasi ustaz dan narapidana di pesantren narapidana lembaga pemasyarakatan kelas II A Kota Lubuklinggau sangat membawa dampak positif. Karena beberapa narapidana sudah menunjukkan respon positif selama mendapatkan binaan di pesantren ini.

2. Berdasarkan hasil observasi, wawancara dan dokumentasi maka peneliti mendapatkan hasil bahwa pelaksanaan manajemen strategi di lembaga pemasyarakatan kelas II A Kota Lubuklinggau berjalan maksimal walaupun belum dalam ruang lingkup yang luas. 


\section{DAFTAR PUSTAKA}

Abdullah, R. H. (2015). Urgensi penggolongan narapidana dalam lembaga pemasyarakatan. Fiat Justisia: Jurnal Ilmu Hukum, 9(1). https://doi.org/10.25041/fiatjustisia. v9no1.587

Arikunto, S. (1992). Prosedur penelitian: Suatu pendekatan praktik. Rineka Cipta.

Bahagiati, K. (2020). Filsafat pemidanaan terhadap penyalah guna narkotika bagi diri sendiri dalam perspektif hukum positif dan hukum pidana islam. Era Hukum-Jurnal Ilmiah Ilmu Hukum, 18(1).

Banyak Napi Bawa Handphone Dalam Sel, Kanwil Kemenkumham Sumsel Bakal Pasang X-Ray di Tiap Lapas. (n.d.). Retrieved from https://sumsel.tribunnews.com/202 0/09/08/banyak-napi-bawahandphone-dalam-sel-kanwilkemenkumham-sumsel-bakalpasang-x-ray-di-tiap-lapas

Dendy Aprihadi. (2019, November 4). Wawancara Proses Pembinaan Napi Lapas Kelas II A Kota Lubuklinggau [Wawancara].

Dwiatmodjo, H. (2013). Pelaksanaan pidana dan pembinaan narapidana tindak pidana narkotika (Studi terhadap Pembinaan Narapidana di Lembaga Pemasyarakatan Narkotika Klas IIA Yogyakarta). Perspektif, 18(2), 64-73. https://doi.org/10.30742/perspektif. v18i2.115

Dzulkipli. (2019, November 10). Wawancara Tentang Proses Pembinaan Agama Napi Lapas Kelas
II A Kota Lubuklinggau

[Wawancara].

Faizah, F. (2015). Psikologi Dakwah. Jakarta: Prenada Media.

Harsono, C. I. (1995). Sistem baru pembinaan narapidana. Jakarta: Djambatan.

Hutabarat, R. R. (2017). Problematika Lembaga Pemasyarakatan dalam Sistem Peradilan Terpadu. Jurnal Muara Ilmu Sosial, Humaniora, Dan Seni, 1(1), 42-50.

Imam Purwanto. (2019, November 12). Wawancara Tentang Tugas Pokok Lembaga Permasyarakatan Kelas II A Kota Lubuklinggau [Wawancara].

Indonesia, C. N. N. (n.d.). Angka Kriminalitas Naik, Polri Fokus Empat Kasus Kejahatan. Retrieved October 6, 2020, from Nasional website:

https://www.cnnindonesia.com/na sional/20190517062637-12395609/angka-kriminalitas-naikpolri-fokus-empat-kasus-kejahatan Murman. (2019, November 12).

Wawancara Tentang Konsep Pembinaan Napi Lapas Kelas II A Kota Lubuklinggau [Wawancara].

Novita. (2019, November 12). Wawancara Tentang Denah Lokasi Lapas Kelas II A Kota Lubuklinggau [Wawancara].

Prawira, O. Y., \& Suteki, S. (2017).

Diskresi petugas lembaga pemasyarakatan perempuan kelas ii a, semarang:(telaah paradigma konstruktivisme tentang pelaksanaan undang-undang nomor 12 tahun 1995 tentang pemasyarakatan). disertasi, Universitas Diponegoro. 
Purba, B., Gaspersz, S., Bisyri, M., Putriana, A., Hastuti, P., Sianturi, E., ... Djalil, N. A. (2020). Ilmu Komunikasi: Sebuah Pengantar. Medan: Yayasan Kita Menulis.

Putra, A. S., Yuliartini, N. P. R., \& Mangku, D. G. S. (2020). Sistem pembinaan terhadap narapidana narkotika di lembaga pemasyarakatan kelas ii $\mathrm{b}$ singaraja. Jurnal Komunitas Yustisia, 2(2), 1-10.

Rahmah, N. (2017). Sistem Keamanan di Lembaga Pemasyarakatan Klas II A Bollangi-Sungguminasa Terhadap Kemungkinan Terjadinya Narapidana Melarikan Diri.

Rodiyah, A., Dirlanudin, D., \& Cadith, J. (2018). Analisis swot terhadap dinas pendidikan dan kebudayaan kota serang dalam menanggulangi pemberantasan buta aksara di kota serang.

Sadli Putra. (2019, November 12). Wawancara satu perangkat peradilan pidana Lapas Kelas II A Kota Lubuklinggau [Wawancara].

Sandi, A. (2016). Narkoba dari Tapal Batas Negara. Bandung: Mujahidin Press.

Setiawan, A. A., Johan. (2018). Metodologi penelitian kualitatif. Sukabumi: CV Jejak (Jejak Publisher).

Sugiyono. (2008). Metode penelitian pendidikan: (Pendekatan kuantitatif, kualitatif dan $R \mathcal{E} D$ ). Bandung: Alfabeta.

Sugiyono. (2013). Memahami Penelitian Kualitatif. Bandung: Alfabeta. Sujarweni, V. W. (2014). Metodologi Penelitian. Lengkap, Praktis, dan
Mudah Dipahami. Bantul: Pustaka Baru Press.

Susriyanti, S., \& Nardo, R. (2019).

Pengaruh fungsi komunikasi dan kepuasan kerja karyawan terhadap pemberian pelayanan nasabah PT. BPR LPN Talawi Sakato. Jurnal Administrasi Sosial Dan Humaniora, 3(2), 97-111.

Tohari, A., \& Rokhim, A. (2020). Tinjauan hukum bidang pembinaan dan pengamanan terhadap anggota polri yang melakukan penyalahgunaan narkoba berdasarkan peraturan pemerintah ri nomor 2 tahun 2003 tentang peraturan disiplin anggota polri. Legalitas, 4(2), 54-71.

Uu-no-12-tahun-1995-tentangpemasyarakatan. (n.d.). Kemenkumham.

Wibawa, I. (2018). Pidana Kerja Sosial dan Restitusi Sebagai Alternatif Pidana Penjara dalam Pembaharuan Hukum Pidana Indonesia. Media Hukum, 24(2), 96104.

Wismabrata, M. H. (2018, November 30). 5 Fakta di Balik Ratusan Napi Kabur dari LP Aceh Besar, Sipir Kalah Jumlah hingga Kronologi Kerusuhan Halaman allKompas.com. Retrieved December 26, 2020, from https://regional.kompas.com/read/ 2018/11/30/10413371/5-fakta-dibalik-ratusan-napi-kabur-dari-lpaceh-besar-sipir-kalahjumlah?page $=$ all 